\title{
REFERENCES
}

1. Coats, George.-Trans. Ophthal. Soc. U.K., Vol. XXXII, p. 52, 1912.

2. Proc. Roy. Soc. Med., Vol. VII, 1913.

3. Vogt, A.-Atlas der Spaltlampe, 2nd edition Vol. I.

4. Gallemaerts, E.-Examen microscopique des affections de la cornée au moyen de la lampe à fente. 1926.

5. Caspar.-Subepitheliale Trübungsfiguren der Hornhaut, nach Verletzungen. Klin. Monatsbl.f. Augenheilk., Vol. LVII, p. 385, 1916.

6. Meller -Ueber die post-traumatischen Ringtrübungen der Hornhaut. Klin. Monatsbl.f. Augenheilk, Vol. LIX, p. 62, 1917.

7. Pichler.-Die Casparsche Ringtrübung der Hornbaut. Zeitschr. f. Augenheilk., Vol. XXXVI; p. 311, 1916.

8. Palich-Szanto.-Scheibenförmige Hornhaut-trübung nach Trauma. Klin. Monatsbl.f. Augenheilk., Vol. LIX, p. 425, 1917.

9. Lampert. Contusion fraiche de la cornée vue à la loupe à fente. Arch. franc. d'Ophtal., Vol. XLI, p. 567, 1924.

10. Cicatrices de la cornée à lampe à fente. Bull. Soc. frang. d'Ophtal., p. $391,1925$.

11. Vogt.-Frischgeschlossene Hornhautepitheldefekte. Arch.f. Ophthal., Vol. CVI, p. 66.

12. Rindfleisch.-Arch. f: Ophthal., Vol. XXXVII, p. 236, 1891.

13. Elschnig.-Klin. Monatsbl.f. Augenheilk. December, 1899.

14. Meissner.-Bericht. der Deutschen Ophthal. Gesellschaft. Vol. XLII, p. 334. (Zentralblatt, Vol. V, p. 57).

15. Seefelder.-Ophthal. Ges. v. Wien. Sitzung. Von 19/4/20. (Zeitschr. f. Augenheilk., Vol. XLIV, H. 3/4, p. 220).

16. Koeppe. Arch.f. Ophthal., Vol. XCIV, p. 250, 1919.

\section{"WHITE RINGS" IN THE CORNEA}

$$
\text { BY }
$$

\section{S. MAYOU}

LONDON

A. J. Ballantyne in the current number of the Brit. Jl. of Ophthal. writes on some cases of "white rings" in the cornea, a condition originally described by Coats. This is of such rarity that the following case is of interest :-

E. C. P., male, aged 50 years. Seen on March 21, 1933, suffering from mild keratitis profunda. An interstitial opacity, which amounted to little more than a haze, was situated in the deepest layers of the cornea. There was no keratitis punctata, the Wassermann Reaction was negative and the condition was apparently due to a septic condition of the antrum and ethmoidal sinuses.

On examining the cornea with a slit-lamp, down and in could be seen a ring of white dots situated immediately beneath the epithelium, which was perfectly smooth over it. The dots were discrete, sharply defined and brilliant white in appearance. They 

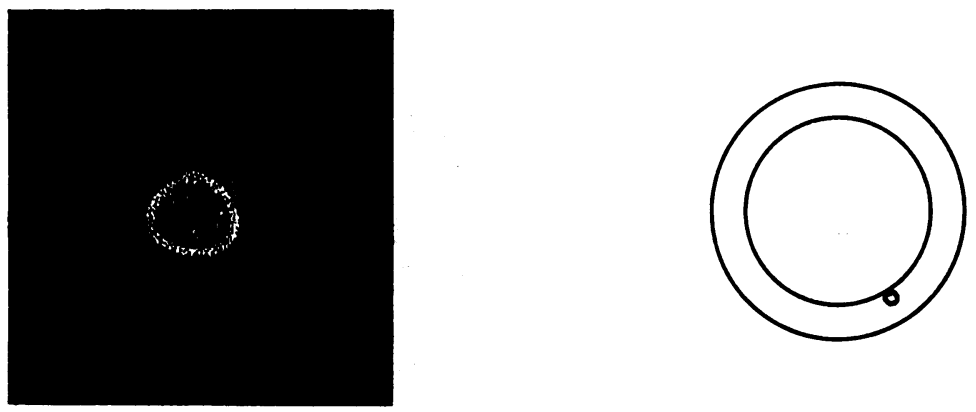

had obviously no connection with the interstitial opacity in the deeper layers of the cornea. There was no suggestion that they were due to injury or deposits of lead or other change, and I am inclined to think with Coats that the condition might be congenital.

\section{HAEMORRHAGE INTO A PROLAPSED VITREOUS POUCH}

BY

\section{T. HARRISON BUTLER}

BIR M I NGHAM

THE exact structure of the vitreous is still open to discussion, and any evidence which bears upon the subject is of value.

Examination of the vitreous with the slit-lamp shows a series of waving membranes one behind the other. When the eye is moved, these membranes float up and slowly return to their vertical position. This is the usual appearance, but variations are common. In some cases the vitreous seems much more homogeneous, in a few it appears to be full of fibrils like cotton threads. When the vitreous degenerates the floating membranes disappear; the structure is simplified; and instead of membranes we see floating strands and particles.

Duke-Elder and others think that the membranes are merely optical phenomena. Ida C. Mann believes that there are real membranes in the central part of the vitreous representing Cloquet's Canal. The more one observes these membranes and their behaviour, the more one feels that they are real anatomical structures; whether they fill the whole vitreous or merely the central visible part must be a matter of conjecture.

I have recently had under my care at The West Bromwich Hospital, a case with features which greatly strengthen the view 